\title{
Nitrogen isotopic evidence for a shift from nitrate- to diazotroph-fueled export production in the VAHINE mesocosm experiments
}

\author{
Angela N. Knapp ${ }^{1}$, Sarah E. Fawcett ${ }^{2,3}$, Alfredo Martínez-Garcia ${ }^{4}$, Nathalie Leblond ${ }^{5}$, Thierry Moutin ${ }^{5}$, and \\ Sophie Bonnet ${ }^{5}$ \\ ${ }^{1}$ Earth, Ocean, and Atmospheric Science Department, Florida State University, 117 N Woodward AVE, \\ Tallahassee, FL, 32306, USA \\ ${ }^{2}$ Department of Geosciences, Guyot Hall, Princeton University, Princeton, NJ 08544, USA \\ ${ }^{3}$ Department of Oceanography, University of Cape Town, Rondebosch, 7701, South Africa \\ ${ }^{4}$ Max Plank Institute for Chemistry, Hahn-Meitner-Weg 1, 55128 Mainz, Germany \\ ${ }^{5}$ Mediterranean Institute of Oceanography (MIO), IRD/CNRS/Aix-Marseille University, IRD Noumea, \\ 101 Promenade R. Laroque, BPA5, 98848 Noumea Cedex, France
}

Correspondence to: Angela N. Knapp (anknapp@fsu.edu)

Received: 14 November 2015 - Published in Biogeosciences Discuss.: 14 December 2015

Revised: 21 July 2016 - Accepted: 29 July 2016 - Published: 18 August 2016

\begin{abstract}
In a coastal lagoon with a shallow, $25 \mathrm{~m}$ water column off the southwest coast of New Caledonia, large-volume $\left(\sim 50 \mathrm{~m}^{3}\right)$ mesocosm experiments were undertaken to track the fate of newly fixed nitrogen $(\mathrm{N})$. The mesocosms were intentionally fertilized with $0.8 \mu \mathrm{M}$ dissolved inorganic phosphorus to stimulate diazotrophy. $\mathrm{N}$ isotopic evidence indicates that the dominant source of $\mathrm{N}$ fueling export production shifted from subsurface nitrate $\left(\mathrm{NO}_{3}^{-}\right)$assimilated prior to the start of the 23-day experiments to $\mathrm{N}_{2}$ fixation by the end of the experiments. While the $\delta^{15} \mathrm{~N}$ of the sinking particulate $\mathrm{N}\left(\mathrm{PN}_{\text {sink }}\right)$ flux changed during the experiments, the $\delta^{15} \mathrm{~N}$ of the suspended PN ( $\left.\mathrm{PN}_{\text {susp }}\right)$ and dissolved organic $\mathrm{N}$ (DON) pools did not. This is consistent with previous observations that the $\delta^{15} \mathrm{~N}$ of surface ocean $\mathrm{N}$ pools is less responsive than that of $\mathrm{PN}_{\text {sink }}$ to changes in the dominant source of new $\mathrm{N}$ to surface waters. In spite of the absence of detectable $\mathrm{NO}_{3}^{-}$in the mesocosms, the $\delta^{15} \mathrm{~N}$ of $\mathrm{PN}_{\text {sink }}$ indicated that $\mathrm{NO}_{3}^{-}$continued to fuel a significant fraction of export production (20 to $60 \%$ ) throughout the 23-day experiments, with $\mathrm{N}_{2}$ fixation dominating export after about 2 weeks. The low rates of organic $\mathrm{N}$ export during the first 14 days were largely supported by $\mathrm{NO}_{3}^{-}$, and phytoplankton abundance data suggest that sinking material primarily comprised large diatoms. Concurrent molecular and taxonomic studies
\end{abstract}

indicate that the diazotroph community was dominated by diatom-diazotroph assemblages (DDAs) at this time. However, these DDAs represented a minor fraction $(<5 \%)$ of the total diatom community and contributed very little new $\mathrm{N}$ via $\mathrm{N}_{2}$ fixation; they were thus not important for driving export production, either directly or indirectly. The unicellular cyanobacterial diazotroph, a Cyanothece-like UCYN-C, proliferated during the last phase of the experiments when $\mathrm{N}_{2}$ fixation, primary production, and the flux of $\mathrm{PN}_{\text {sink }}$ increased significantly, and $\delta^{15} \mathrm{~N}$ budgets reflected a predominantly diazotrophic source of $\mathrm{N}$ fueling export. At this time, the export flux itself was likely dominated by the non-diazotrophic diatom, Cylindrotheca closterium, along with lesser contributions from other eukaryotic phytoplankton and aggregated UCYN-C cells, as well as fecal pellets from zooplankton. Despite comprising a small fraction of the total biomass, UCYN-C was largely responsible for driving export production during the last $\sim 10$ days of the experiments both directly ( $\sim 5$ to $22 \%$ of $\mathrm{PN}_{\text {sink }}$ ) and through the rapid transfer of its newly fixed $\mathrm{N}$ to other phytoplankton; we infer that this newly fixed $\mathrm{N}$ was transferred rapidly through the dissolved

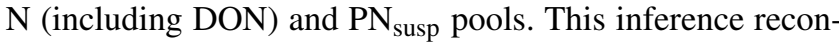
ciles previous observations of invariant oligotrophic surface ocean DON concentrations and $\delta^{15} \mathrm{~N}$ with incubation studies 
showing that diazotrophs can release a significant fraction of their newly fixed $\mathrm{N}$ as some form of DON.

\section{Introduction}

One of the primary pathways by which carbon dioxide $\left(\mathrm{CO}_{2}\right)$ is removed from the atmosphere is via photosynthesis, through which it is converted into organic carbon. In the ocean, this process is known as the "biological pump" since upon death, the phytoplankton that fixed inorganic carbon into biomass in surface waters are eventually transported to depth (either via passive sinking or as a byproduct of grazing), thereby "pumping" the carbon to deep waters where it remains isolated from the atmosphere on hundredto thousand-year timescales. In broad regions of the surface ocean, the scarcity of the essential macronutrient, nitrogen (N), limits photosynthesis and thus the capacity of the biological pump to remove $\mathrm{CO}_{2}$ from the atmosphere (Falkowski, 1997). Consequently, there is considerable interest in quantifying fluxes of $\mathrm{N}$ to the ocean, as well as in understanding the fate of that $\mathrm{N}$ once it enters the ocean.

In addition to lesser contributions from rivers and atmospheric deposition, the dominant source of $\mathrm{N}$ to the ocean is biologically mediated di-nitrogen $\left(\mathrm{N}_{2}\right)$ fixation (Gruber, 2004). Marine cyanobacteria, bacteria, and archaea that can access the abundant dissolved $\mathrm{N}_{2}$ gas pool as a source of assimilative $\mathrm{N}$ are known as diazotrophs and have a competitive advantage over other microbes and phytoplankton that require an exogenous source of $\mathrm{N}$ such as nitrate $\left(\mathrm{NO}_{3}^{-}\right)$, ammonium $\left(\mathrm{NH}_{4}^{+}\right)$, and/or dissolved organic N (DON). Several geochemical signals that accumulate in the thermocline of the oligotrophic gyres are thought to result from diazotrophic activity in overlying surface waters. In particular, diazotrophic biomass has elevated $\mathrm{N}$ to phosphorus (P) ratios ( $\sim 25: 1$ to $50: 1$; Holl and Montoya, 2008; Krauk et al., 2006; Kustka et al., 2003; White et al., 2006) relative to typical (i.e., "Redfieldian") marine biomass ( $\sim 16: 1$ N : P; Falkowski, 2000; Redfield, 1958; Sterner and Elser, 2002). The death of diazotrophs and subsequent remineralization of their biomass in the thermocline can cause $\mathrm{NO}_{3}^{-}$to phosphate $\left(\mathrm{PO}_{4}^{3-}\right)$ concentration ratios $>16: 1$ in regions associated with high rates of $\mathrm{N}_{2}$ fixation (Gruber and Sarmiento, 1997; Hansell et al., 2004). Combining inventories of elevated subsurface $\mathrm{NO}_{3}^{-}: \mathrm{PO}_{4}^{3-}$ concentration ratios with timescales over which the signal has accumulated has been used to estimate basin-scale rates of marine $\mathrm{N}_{2}$ fixation (Deutsch et al., 2001; Eugster and Gruber, 2012; Gruber and Sarmiento, 1997). Additionally, the $\mathrm{NO}_{3}^{-}$accumulating in the thermocline as a result of diazotrophic activity has a $\mathrm{N}$ isotopic composition (" $\delta{ }^{15} \mathrm{~N}$ ") of $\sim-2$ to $0 \%$ (Carpenter et al., 1997; Hoering and Ford, 1960; Minagawa and Wada, 1986), which is distinct from that of mean ocean $\mathrm{NO}_{3}^{-}, \sim 5 \%$ (Sigman et al., 2009;
" $\delta{ }^{15} \mathrm{~N}$ ", where $\delta^{15} \mathrm{~N}=\left\{\left[\left({ }^{15} \mathrm{~N} /{ }^{14} \mathrm{~N}\right)\right)_{\text {sample }} /\left({ }^{15} \mathrm{~N} /{ }^{14} \mathrm{~N}\right)\right.$ reference $]$ $-1\} \times 1000$, with atmospheric $\mathrm{N}_{2}$ as the reference). Consequently, regions of the ocean associated with elevated rates of $\mathrm{N}_{2}$ fixation accumulate low- $\delta^{15} \mathrm{~N} \mathrm{NO}_{3}^{-}$in the same water masses that host elevated $\mathrm{NO}_{3}^{-}: \mathrm{PO}_{4}^{3-}$ concentration ratios; the accumulation of this low- $\delta^{15} \mathrm{~N} \mathrm{NO}_{3}^{-}$has also been used to estimate basin-scale $\mathrm{N}_{2}$ fixation rates (Knapp et al., 2008).

While geochemical evidence indicates that the high $\mathrm{N}: \mathrm{P}$ ratios and low $\delta^{15} \mathrm{~N}$ of diazotrophic biomass is ultimately incorporated into the upper thermocline of the tropical and subtropical ocean, the pathways by which these geochemical signatures are transferred from the surface to subsurface ocean remain enigmatic. For example, the conspicuous marine diazotroph Trichodesmium spp. is thought to be grazed by only a small number of zooplankton (O'Neill and Roman, 1994; Roman, 1978), suggesting that this diazotroph may not be transferred up the food web in the same way as other phytoplankton. Additionally, due to the presence of buoyant gas vacuoles, Trichodesmium spp. may not sink as efficiently as other phytoplankton, potentially explaining why its biomass is often not observed in sediment traps (Walsby, 1992). This renders sinking upon death, another common fate of phytoplankton biomass, a less likely pathway by which newly fixed $\mathrm{N}$ may leave surface waters.

Instead of being transferred up the food web to higher trophic levels or being removed via sinking, newly fixed $\mathrm{N}$ has been thought to play a critical role in supporting the microbial loop through the release of DON and $\mathrm{NH}_{4}^{+}$. Programmed cell death (Berman-Frank et al., 2004), grazing (Glibert and Bronk, 1994), and direct release (Capone et al., 1994) have been invoked as mechanisms by which Trichodesmium spp. may release $\mathrm{DON}$ and $\mathrm{NH}_{4}^{+}$to surrounding waters. While consumption of this diazotroph derived $\mathrm{N}$ (DDN) would retain its low- $\delta^{15} \mathrm{~N}$ signature in the event that the DDN consumers eventually sink into the thermocline, it leaves unclear the mechanism by which an elevated $\mathrm{NO}_{3}^{-}: \mathrm{PO}_{4}^{3-}$ concentration ratio accumulates in the thermocline, since the micro-organisms consuming the DDN would likely do so at or close to Redfield stoichiometry. Moreover, there is little field evidence of DON concentrations increasing, or the $\delta^{15} \mathrm{~N}$ of DON decreasing, in regions (Knapp et al., 2011) or periods (Knapp et al., 2005) of high $\mathrm{N}_{2}$ fixation relative to regions and/or times with low rates of $\mathrm{N}_{2}$ fixation. Consequently, while many pathways have been explored, the fate of newly fixed $\mathrm{N}$ remains obscure.

One geochemical tool that has been used to track the fate of DDN, as well as to quantify its contribution to export production, is the upper ocean $\delta^{15} \mathrm{~N}$ budget. Comparing the distinct $\delta^{15} \mathrm{~N}$ of subsurface $\mathrm{NO}_{3}^{-}$and newly fixed $\mathrm{N}$, the two dominant sources of new $\mathrm{N}$ to surface waters, with the $\delta^{15} \mathrm{~N}$ of the export flux ("PN $\mathrm{PN}_{\text {sink }} \delta^{15} \mathrm{~N}$ ") provides an integrative measure of the relative contributions of subsurface $\mathrm{NO}_{3}^{-}$and $\mathrm{N}_{2}$ fixation to export production (e.g., Altabet, 1988; Casciotti et al., 2008; Dore et al., 2002; Karl et al., 1997; Knapp 
et al., 2005; Liu et al., 1996). Assigning newly fixed $\mathrm{N}$ a $\delta^{15} \mathrm{~N}$ of $-1 \%$, the fractional importance of $\mathrm{N}_{2}$ fixation for supporting export production $(x)$ in an upper ocean $\delta^{15} \mathrm{~N}$ budget can be expressed as follows:

$\mathrm{PN}_{\text {sink }} \delta^{15} \mathrm{~N}=x(-1 \% \circ)+(1-x)\left(\mathrm{NO}_{3}^{-} \delta^{15} \mathrm{~N}\right)$.

Rearranging and solving for $x$ yields the following:

$x=\left(\mathrm{NO}_{3}^{-} \delta^{15} \mathrm{~N}-\mathrm{PN}_{\mathrm{sink}} \delta^{15} \mathrm{~N}\right) /\left(1+\mathrm{NO}_{3}^{-} \delta^{15} \mathrm{~N}\right)$.

Multiplying the fraction of export production supported by $\mathrm{N}_{2}$ fixation $(x)$ by the $\mathrm{PN}_{\text {sink }}$ mass flux provides a timeintegrated $\mathrm{N}_{2}$ fixation rate that can be compared with ${ }^{15} \mathrm{~N}_{2}$ incubation-based $\mathrm{N}_{2}$ fixation rate measurements (Knapp et al., 2016). We note that the $\delta^{15} \mathrm{~N}$ of $\mathrm{NO}_{3}^{-}$in the equations above more accurately refers to the $\delta^{15} \mathrm{~N}^{1} \mathrm{NO}_{3}^{-}+$nitrite $\left(\mathrm{NO}_{2}^{-}\right)$; however, $\mathrm{NO}_{2}^{-}$concentrations are typically extremely low throughout the oxidized water column, so for brevity, we refer to $\mathrm{NO}_{3}^{-}+\mathrm{NO}_{2}^{-}$measurements as $\mathrm{NO}_{3}^{-}$measurements.

$\mathrm{N}$ isotope budgets in stratified, oligotrophic gyres consistently indicate that subsurface $\mathrm{NO}_{3}^{-}$supports at least $75 \%$, and often $>90 \%$, of export production, even during the stratified summer season (Altabet, 1988; Casciotti et al., 2008; Fawcett et al., 2011; Knapp et al., 2005, 2016). This is inconsistent with biological assays indicating that $\mathrm{N}_{2}$ fixation supports a higher, and often dominant, fraction of tropical and subtropical export production (e.g., Capone et al., 2005; Montoya et al., 2004). The disagreement between the results of these biological assays and the $\delta^{15} \mathrm{~N}$ budgets (as well as the lack of response in the concentration and/or $\delta^{15} \mathrm{~N}$ of oligotrophic surface ocean DON) raises the following questions: are upper ocean $\delta^{15} \mathrm{~N}$ budgets an appropriate tool for tracking the fate of DDN, and is the $\delta^{15} \mathrm{~N}$ of sinking organic matter diagnostic for the source of $\mathrm{N}$ fueling export production?

To address the fate of DDN and to quantify the contribution of newly fixed $\mathrm{N}$ to export production, large volume $\left(\sim 50 \mathrm{~m}^{3}\right)$ mesocosms were deployed in a region of the southwest Pacific known to support diazotrophy during the austral summer (Bonnet et al., 2015; Dupouy et al., 2000; Rodier and Le Borgne, 2008, 2010) and where $\mathrm{PO}_{4}^{3-}$ availability appears to ultimately control $\mathrm{N}_{2}$ fixation rates (Moutin et al., 2005, 2008). In order to better track the fate of DDN, these mesocosms were intentionally fertilized with $\sim 0.8 \mu \mathrm{M}$ dissolved inorganic phosphorus (DIP) to stimulate diazotrophic activity and thus amplify the biogeochemical signals of $\mathrm{N}_{2}$ fixation. Here, we present $\delta^{15} \mathrm{~N}$ budgets from inside the manipulative mesocosm experiments and discuss how the observed geochemical signals correspond to contemporaneous shifts in diazotroph and phytoplankton community composition.

\section{Methods}

\subsection{Experimental design and sample collection}

A detailed description of the VAHINE mesocosm experiments is provided elsewhere (Bonnet et al., 2016b). Briefly, three $2.3 \mathrm{~m}$ diameter, $15 \mathrm{~m}$ deep $\left(\sim 50 \mathrm{~m}^{3}\right)$ cylinders of impermeable, transparent plastic sheeting (subsequently referred to as M1, M2, and M3) were deployed in shallow waters ( $25 \mathrm{~m}$ water column depth) of the oligotrophic Noumea lagoon, $28 \mathrm{~km}$ from New Caledonia (Bonnet et al., 2016b). Screw-top plastic bottles $(250 \mathrm{~mL})$ were attached to the bottom of the mesocosms to collect $\mathrm{PN}_{\text {sink }}$. These "sediment trap" samples were collected daily by SCUBA divers and "swimmers" were removed from them prior to analysis. Water column samples were collected daily at $6 \mathrm{~m}$ depth from each of the three mesocosms throughout the 23-day experiment. Discrete samples for nutrients including $\mathrm{NO}_{3}^{-}+\mathrm{NO}_{2}^{-}$ and $\mathrm{NH}_{4}^{+}$, suspended particulate $\mathrm{N}$ ( $\mathrm{PN}_{\text {susp }}$ ), and total $\mathrm{N}$ $\left(\mathrm{TN}=\mathrm{PN}_{\text {susp }}+\mathrm{DON}+\mathrm{NO}_{3}^{-}+\mathrm{NO}_{2}^{-}+\mathrm{NH}_{4}^{+}\right)$were collected by pumping water via $\mathrm{PVC}$ tubing connected to a teflon pump (Astii) into $50 \mathrm{~L}$ polyethylene carboys atop a floating platform. The $50 \mathrm{~L}$ carboys were transferred to the R/V Alis and immediately subsampled on deck for the discrete samples described above. Finally, samples were also collected at a control site near the mesocosms (subsequently referred to as "Noumea lagoon waters") to monitor biogeochemical conditions outside of the manipulative mesocosm experiments.

To stimulate diazotrophy, DIP was added on the evening of the fourth day of the experiments to reach a final concentration of $\sim 0.8 \mu \mathrm{M}$ in each mesocosm. As described in (Bonnet et al., 2016b), this was achieved by pumping a $20 \mathrm{~L}$ concentrated DIP stock solution throughout the $15 \mathrm{~m}$ water column of each mesocosm.

\subsection{Nitrogen concentration and $\delta^{15} \mathrm{~N}$ analyses}

A detailed description of the sample collection, analysis, and results of dissolved inorganic $\mathrm{N}$ (DIN) measurements made in the VAHINE mesocosm experiments is described elsewhere (Berthelot et al., 2015; Bonnet et al., 2016b). Briefly, the concentration of $\mathrm{NH}_{4}^{+}$was determined using a fluorometric method (Holmes et al., 1999) with a detection limit of $0.01 \mu \mathrm{M}$, the concentration of $\mathrm{NO}_{3}^{-}+\mathrm{NO}_{2}^{-}$was determined using colorimetric methods (Strickland and Parsons, 1968) with a detection limit of $0.01 \mu \mathrm{M}$, and the concentration of $\mathrm{PN}_{\text {susp }}$ was determined by wet oxidation (Pujo-Pay and Raimbault, 1994) with a quantification limit of $0.06 \mu \mathrm{M}$. The $\delta^{15} \mathrm{~N}$ of $\mathrm{PN}_{\text {susp }}$ was determined by filtering seawater through a pre-combusted, acid-washed Whatman GF/F (nominal pore size of $0.7 \mu \mathrm{m}$ ), followed by high-temperature combustion of the filter coupled with isotope ratio mass spectrometry using a Delta Plus Thermo Fisher Scientific mass spectrometer as described in (Berthelot et al., 2015). 
The concentration of TN for samples collected at the same time and in the same manner as the DIN samples described above was determined by persulfate oxidation (Solorzano and Sharp, 1980) with adaptations (Knapp et al., 2005), and the resulting $\mathrm{NO}_{3}^{-}$was measured by chemiluminescence (Braman and Hendrix, 1989). DON concentration was determined by subtracting the concentrations of $\mathrm{PN}_{\text {susp }}, \mathrm{NH}_{4}^{+}$, and $\mathrm{NO}_{3}^{-}+\mathrm{NO}_{2}^{-}$(reported in Berthelot et al., 2015) from the measured TN concentration of each sample with a propagated error of $\pm 0.5 \mu \mathrm{M}$. The $\delta^{15} \mathrm{~N}$ of $\mathrm{NO}_{3}^{-}+\mathrm{NO}_{2}^{-}$was measured using the denitrifier method (Casciotti et al., 2002; McIlvin and Casciotti, 2011; Sigman et al., 2001) with a typical standard deviation of $\pm 0.2 \%$. The $\delta^{15} \mathrm{~N}$ of TN was determined via persulfate oxidation of $\mathrm{TN}$ to $\mathrm{NO}_{3}^{-}$(Knapp et al., 2005) and subsequent analysis of $\mathrm{NO}_{3}^{-} \delta^{15} \mathrm{~N}$ by the denitrifier method, with a propagated error for DON $\delta^{15} \mathrm{~N}$ calculated using a Monte Carlo method (Press et al., 1992) of $\pm 0.6 \%$. Finally, the $\delta^{15} \mathrm{~N}$ of $\mathrm{PN}_{\text {sink }}$ was measured using a Thermo Scientific Flash 2000 Elemental Analyzer coupled with a Delta Plus Thermo Scientific mass spectrometer. The average standard deviation for the standards analyzed was $\pm 0.06 \%$.

\section{Results}

The intentional DIP fertilization of the mesocosms on the fourth evening of the VAHINE experiments lends temporal structure to the 23-day course of observations. Three distinct phases are evident based on multiple biogeochemical metrics: days 1 to 4, prior to DIP fertilization (subsequently referred to as "P0"), which largely reflect "background" conditions; days 5 to 14, after DIP fertilization (subsequently referred to as "P1"), characterized by a much longer DIP turnover time than $\mathrm{P} 0$; and finally, days 15 to 23 (subsequently referred to as "P2"), during which DIP concentrations decreased and biomass, primary production, and $\mathrm{N}_{2}$ fixation rates increased (Berthelot et al., 2015; Bonnet et al., 2016b). Differences in the community composition of phytoplankton and diazotrophs (Leblanc et al., 2016; Turk-Kubo et al., 2015) were also evident among the three phases of the VAHINE experiments. Consequently, the results described below are evaluated within the temporal context of the observed biogeochemical changes in the mesocosms.

\subsection{DON concentration and $\delta^{15} \mathrm{~N}$}

Concentrations of DON within the mesocosms showed no significant change over the course of the 23-day experiments (Fig. 1a). Average DON concentrations in M1, M2, and $\mathrm{M} 3$ were $5.4 \pm 0.3,5.3 \pm 1.1$, and $5.5 \pm 0.6 \mu \mathrm{M}$, respectively. These concentrations are consistent with previous observations from surface waters of other oligotrophic ocean regions (Knapp et al., 2011; Letscher et al., 2013), as well as with the DON concentration of $5.4 \mu \mathrm{M}$ in Noumea lagoon waters

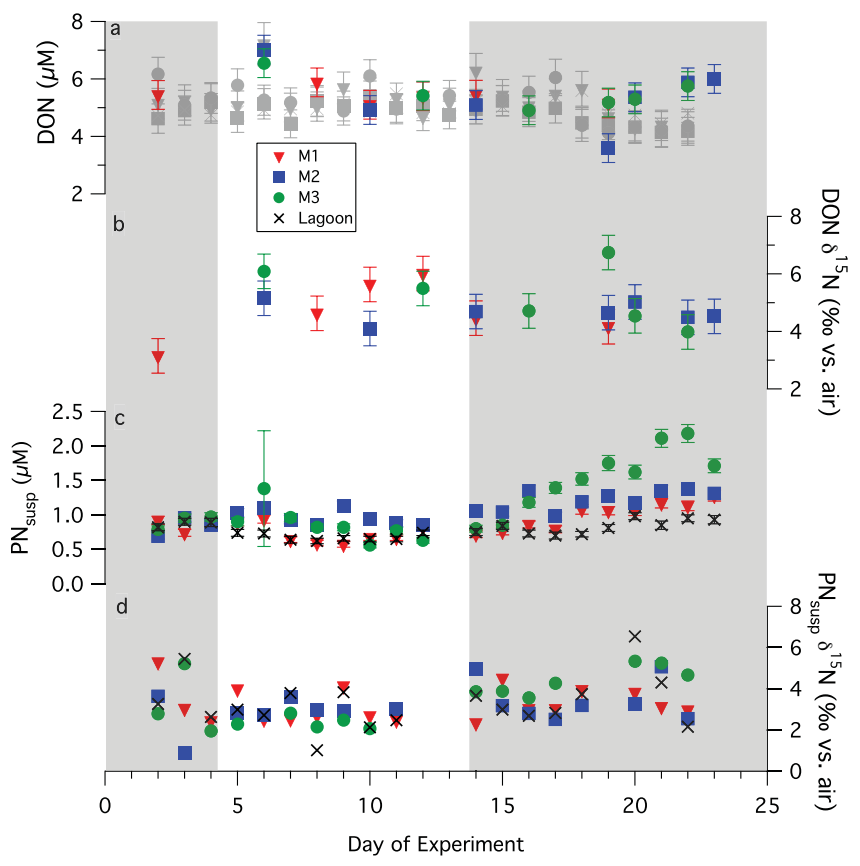

Figure 1. VAHINE water column DON concentration measurements from this study in color overlain upon those of Berthelot et al. (2015), in gray (a), DON $\delta^{15} \mathrm{~N}$ (b), $\mathrm{PN}_{\text {susp }}$ concentration (c), and $\mathrm{PN}_{\text {susp }} \delta^{15} \mathrm{~N}$ (d) from within M1 (red filled inverted triangles), M2 (blue filled squares), M3 (green filled circles), and in the lagoon waters outside the mesocosms ("X" symbols). Error bars represent propagated error for DON concentration and DON $\delta^{15} \mathrm{~N}$, and $\pm 1 \mathrm{SD}$ for $\mathrm{PN}_{\text {susp }}$ concentration. No replicate measurements of $\mathrm{PN}_{\text {susp }} \delta^{15} \mathrm{~N}$ were made, so no error bars are shown. Shaded regions indicate P0 (days 1 through 4) and P2 (days 15 through 23), with the unshaded region in between indicating P1 (days 5 through 14).

measured outside the mesocosms. However, while our observation of invariant DON concentrations over the duration of the experiments are largely similar to those reported by Berthelot et al. (2015), the DON concentration that we measured for three samples collected at the end of P2 diverge from those of Berthelot et al. (2015) who report decreasing DON concentrations (of $\sim 0.9 \mu \mathrm{M}$ ) in all three mesocosms during $\mathrm{P} 2$ compared to $\mathrm{P} 0$ and $\mathrm{P} 1$. For comparison, Fig. 1a shows DON concentration measurements from this study overlain upon those of Berthelot et al. (2015). We note that our DON sampling resolution was not as high as that of Berthelot et al. (2015), so it is possible that we missed the decrease in DON concentration in the mesocosms. The Berthelot et al. (2015) DON concentration decrease, which they attribute to consumption by phytoplankton and/or heterotrophic bacteria, was not accompanied by a decrease in DOC concentration, which given typical $\mathrm{C}: \mathrm{N}$ ratios for marine dissolved organic matter (DOM) of 12 to 14 (Benner, 2002), would be expected to decline by $\sim 9$ to $12 \mu \mathrm{M}$. Since both TN sample sets were collected at the same time and in 
the same manner, and since the DON concentration calculated by mass balance in both cases used the same DIN and $\mathrm{PN}_{\text {susp }}$ measurements reported by (Berthelot et al., 2015), the only measurement contributing to the discrepancy is that of TN. We note that slightly different reagents were used to chemically oxidize $\mathrm{TN}$ to $\mathrm{NO}_{3}^{-}$; while (Berthelot et al., 2015) used the wet-oxidation method of (Pujo-Pay and Raimbault, 1994), the TN measurements reported here were made with a reagent that contained no boric acid and a higher sodium hydroxide concentration (Fawcett et al., 2011; Knapp et al., 2005). In addition, the potassium persulfate was recrystallized four times, then rinsed with GC-grade methanol to speed drying and remove $\mathrm{N}$ contamination to facilitate isotopic analysis (Fawcett et al., 2014; Higgins et al., 2009). We cannot explain the discrepancy between the DON concentration measurements for samples collected at the end of P2 in this study and those reported by Berthelot et al. (2015); given that our samples were also measured for DON $\delta^{15} \mathrm{~N}$ (discussed below), we interpret the data presented in this study in the context of our DON concentration measurements rather than those of Berthelot et al. (2015). We note, however, that regardless of the DON concentration used, the conclusions from our $\delta^{15} \mathrm{~N}$ budget remain the same (see Sect. 4.1 below).

Similar to the concentration of DON, the $\delta^{15} \mathrm{~N}$ of DON showed no significant change over the course of the experiments (Fig. 1b, Table 1). The average DON $\delta^{15} \mathrm{~N}$ in M1, $\mathrm{M} 2$, and M3 was $4.7 \pm 1.0,4.7 \pm 0.4$, and $5.3 \pm 1.0 \%$ o, respectively. The $\delta^{15} \mathrm{~N}$ of DON in the VAHINE mesocosms is similar to that reported previously for the North Pacific gyre (4.7\%o), where the similarity of the $\delta^{15} \mathrm{~N}$ of DON to the $\delta^{15} \mathrm{~N}$ of subsurface $\mathrm{NO}_{3}^{-}$was interpreted to reflect the dominance of subsurface $\mathrm{NO}_{3}^{-}$for fueling export production (Knapp et al., 2011).

\section{2 $\mathrm{PN}_{\text {susp }} \delta^{15} \mathrm{~N}$}

The concentration of $\mathrm{PN}_{\text {susp }}$ (along with the concentrations of suspended particulate organic carbon $\left(\mathrm{PC}_{\text {susp }}\right)$ and phosphorus; $\mathrm{PP}_{\text {susp }}$ ) increased over the course of the experiments (Fig. 1c), most notably during P2, consistent with the observed increase in carbon and $\mathrm{N}_{2}$ fixation during P2 (Berthelot et al., 2015). However, the $\delta^{15} \mathrm{~N}$ of $\mathrm{PN}_{\text {susp }}$ in the mesocosms did not show any significant change with time, and was largely similar to the $\delta^{15} \mathrm{~N}$ of $\mathrm{PN}_{\text {susp }}$ in the lagoon waters (Fig. 1d, Table 1). The average $\delta^{15} \mathrm{~N}$ of $\mathrm{PN}_{\text {susp }}$ in M1, $\mathrm{M} 2$, and $\mathrm{M} 3$ was $3.3 \pm 0.8,3.4 \pm 1.4$, and $3.8 \pm 1.5 \%$, respectively, while the $\delta^{15} \mathrm{~N}$ of $\mathrm{PN}_{\text {susp }}$ outside the mesocosms was $3.3 \pm 1.3 \%$.

\section{3 $\mathrm{PN}_{\text {sink }} \delta^{15} \mathrm{~N}$}

In contrast to the concentration of DON and the $\delta^{15} \mathrm{~N}$ of DON and $\mathrm{PN}_{\text {susp }}$, the $\delta^{15} \mathrm{~N}$ of $\mathrm{PN}_{\text {sink }}$ changed significantly over the course of the experiments (Fig. 2a). Evaluating the $\mathrm{PN}_{\text {sink }} \delta^{15} \mathrm{~N}$ collected in all three mesocosms during $\mathrm{P} 0$,

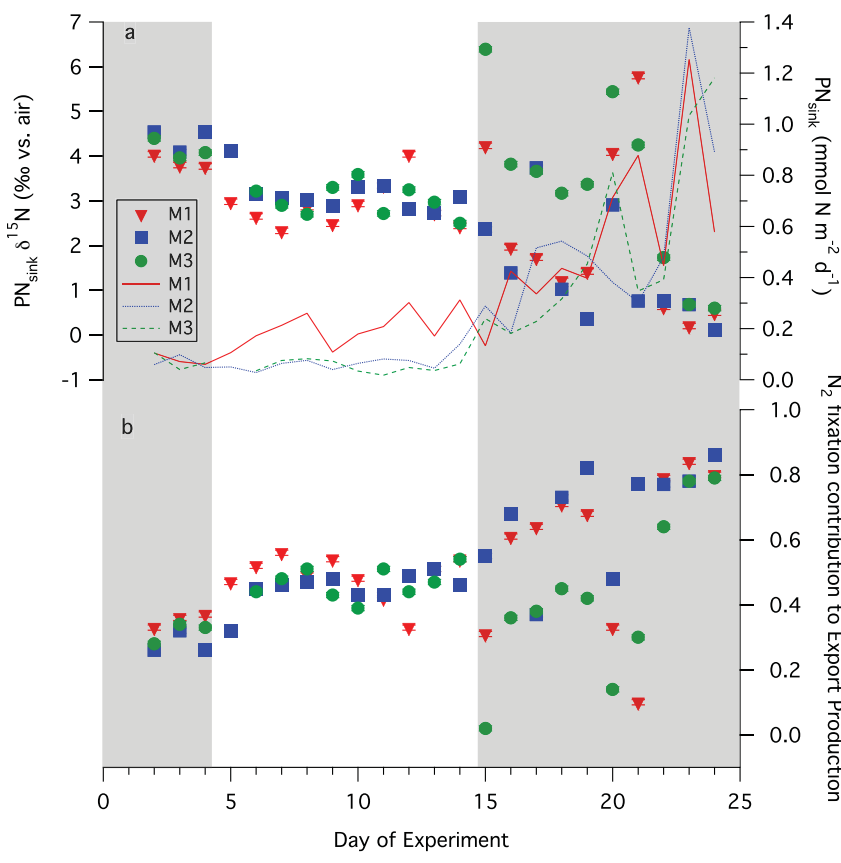

Figure 2. VAHINE $P N_{\text {sink }}$ mass flux in M1 (red solid line), M2 (blue dotted line), and $\mathrm{M} 3$ (green dashed line), and $\mathrm{PN}_{\text {sink }} \delta{ }^{15} \mathrm{~N}$ in M1 (red filled inverted triangles), M2 (blue filled squares), and M3 (green filled circles) (a) and the corresponding contribution of $\mathrm{N}_{2}$ fixation to export production (b). Shaded regions indicate P0 (days 1 through 4) and P2 (days 15 through 23), with the unshaded region in between indicating $\mathrm{P} 1$ (days 5 through 14). $\mathrm{PN}_{\text {sink }} \delta^{15} \mathrm{~N}$ error bars represent an average measurement SD of $\pm 0.06 \%$, and error bars for the fractional contribution of $\mathrm{N}_{2}$ fixation to the $\mathrm{PN}_{\text {sink }}$ flux reflect the $\pm 0.06 \%$ o range associated with the $\mathrm{PN}_{\text {sink }} \delta^{15} \mathrm{~N}$ measurements.

$\mathrm{P} 1$, and P2 with the Kruskal-Wallis rank-sum test for nonparametric data (Triola, 2001) shows that the mean $\delta^{15} \mathrm{~N}$ of $\mathrm{PN}_{\text {sink }}$ for each time period (P0, P1 and P2) is significantly different $(p<0.005)$. Considering the mesocosms individually, the $\delta^{15} \mathrm{~N}$ of $\mathrm{PN}_{\text {sink }}$ for each time period was significantly different for M2 $(p<0.005)$ and potentially for M3 $(0.1>p>0.05)$, but not for M1 $(0.9>p>0.1)$. The average $\mathrm{PN}_{\text {sink }} \delta^{15} \mathrm{~N}$ in $\mathrm{M} 1, \mathrm{M} 2$, and $\mathrm{M} 3$ during $\mathrm{P} 0$ was $3.9 \pm 0.1,4.4 \pm 0.3$, and $4.2 \pm 0.2 \%$, respectively, decreasing to $2.9 \pm 0.5,3.2 \pm 0.4$, and $3.0 \pm 0.3 \%$ during $\mathrm{P} 1$, and $2.2 \pm 1.9,1.4 \pm 1.2$, and $3.3 \pm 1.9 \%$ o during P2 (Fig. 2a). All $\mathrm{PN}_{\text {sink }} \delta^{15} \mathrm{~N}$ measurements for the mesocosms are reported in Table $\mathrm{S} 1$ in the Supplement. 
Table 1. Average concentrations $( \pm 1 \mathrm{SD} ; \mu \mathrm{M})$ and $\delta^{15} \mathrm{~N}(\% \circ)$ for organic $\mathrm{N}$ pools and fluxes in the VAHINE mesocosms during P0 (days 1 through 4), P1 (days 5 through 14), and P2 (days 15 through 23), as well as in the lagoon waters outside the mesocosms. Additionally, the average $( \pm 1 \mathrm{SD})$ fraction of export supported by $\mathrm{N}_{2}$ fixation based on $\delta^{15} \mathrm{~N}$ budget calculations, as well as the average $( \pm 1 \mathrm{SD}) \mathrm{N}_{2}$ fixation rate for each time period based on both $\delta^{15} \mathrm{~N}$ budget calculations and ${ }^{15} \mathrm{~N}_{2}$ incubations (Berthelot et al., 2015), are reported. Note that DON concentration and $\delta^{15} \mathrm{~N}$ for the lagoon and $\mathrm{P} 0$ are based on one measurement, so no standard deviation is included. DIN pool concentrations were low (i.e., $<0.1 \mu \mathrm{M}$ ) and invariant throughout the experiment (Berthelot et al., 2015).

\begin{tabular}{lcccc}
\hline & lagoon & P0 & P1 & P2 \\
\hline$[\mathrm{DON}](\mu \mathrm{M})$ & 5.3 & 5.4 & $5.3 \pm 0.3$ & $5.2 \pm 0.7$ \\
$\mathrm{DON} \delta^{15} \mathrm{~N}(\%)$ & 5.5 & 3.2 & $5.0 \pm 0.7$ & $4.8 \pm 0.7$ \\
{$\left[\mathrm{PN}_{\text {susp }}\right](\mu \mathrm{M})$} & $0.8 \pm 0.1$ & $0.9 \pm 0.1$ & $0.9 \pm 0.2$ & $1.3 \pm 0.4$ \\
$\mathrm{PN}_{\text {susp }} \delta^{15} \mathrm{~N}(\% \circ)$ & $3.3 \pm 1.3$ & $3.2 \pm 1.5$ & $3.4 \pm 1.5$ & $3.7 \pm 0.9$ \\
$\mathrm{PN}_{\text {sink }} \delta^{15} \mathrm{~N}(\%)$ & $\mathrm{NA}$ & $4.1 \pm 0.3$ & $3.0 \pm 0.4$ & $2.3 \pm 1.8$ \\
$\%$ export from $\mathrm{N}_{2}$ fixation & $\mathrm{NA}$ & $32 \pm 4 \%$ & $47 \pm 6 \%$ & $56 \pm 24 \%$ \\
$\delta^{15} \mathrm{~N}$ budget $\mathrm{N}_{2}$ fix. rate & $\mathrm{NA}$ & $23 \pm 8$ & $51 \pm 41$ & $329 \pm 298$ \\
$\left(\mu \mathrm{mol} \mathrm{N} \mathrm{m} \mathrm{d}^{-1}\right)$ & & & & \\
${ }^{15} \mathrm{~N}_{2}$ fix incub. $\mathrm{N}_{2}$ fix. rate & $137 \pm 52$ & $259 \pm 88$ & $150 \pm 61$ & $411 \pm 127$ \\
$\left(\mu \mathrm{mol} \mathrm{N} \mathrm{m} \mathrm{m}^{-2} \mathrm{~d}^{-1}\right)$ & & & & \\
\hline
\end{tabular}

\section{Discussion}

\subsection{The fate of newly fixed $\mathrm{N}$ - pools or fluxes?}

As described above, a primary goal of the VAHINE project was to track the fate of newly fixed $\mathrm{N}$ in manipulative mesocosm experiments (Bonnet et al., 2016b). The $\delta^{15} \mathrm{~N}$ of $\mathrm{PN}_{\text {susp }}$ in the euphotic zone has often been used to infer the dominant $\mathrm{N}$ form fueling primary production, particularly in oligotrophic systems where $\mathrm{NO}_{3}^{-}$and $\mathrm{NH}_{4}^{+}$are typically effectively completely consumed in surface waters (Altabet, 1988; Altabet and McCarthy, 1985; Capone et al., 2005; Treibergs et al., 2014). However, bulk $\mathrm{PN}_{\text {susp }}$ includes compositionally distinct N-containing particles: diverse living autotrophs and heterotrophs as well as detrital organic matter (Fawcett et al., 2011; Rau et al., 1990). In the oligotrophic Sargasso Sea, each of these groups has been shown to have a distinct $\delta^{15} \mathrm{~N}$ signature, with the $\delta^{15} \mathrm{~N}$ of bulk $\mathrm{PN}_{\text {susp }}$ recording their massweighted average (Fawcett et al., 2011, 2014; Treibergs et al., 2014). The $\delta^{15} \mathrm{~N}$ of $\mathrm{PN}_{\text {susp }}$ is also altered by the consumption and production of $\mathrm{N}$ forms recycled in surface waters (e.g., $\mathrm{NH}_{4}^{+}$), the fluxes of which can often greatly exceed the external supply of $\mathrm{N}$ to the euphotic zone (e.g., via $\mathrm{N}_{2}$ fixation or $\mathrm{NO}_{3}^{-}$mixed up from below; Altabet, 1988; Knapp et al., 2011; Lourey et al., 2003). Thus, while the $\delta^{15} \mathrm{~N}$ of $\mathrm{PN}_{\text {susp }}$ may provide some indication of the primary $\mathrm{N}$ source supporting the upper ocean ecosystem, it is unlikely to be a good indicator of the dominant $\mathrm{N}$ form fueling export production (Altabet, 1988; Lourey et al., 2003).

This appears to be the case in the VAHINE mesocosms. The $\delta^{15} \mathrm{~N}$ of $\mathrm{PN}_{\text {susp }}$ remained roughly constant throughout the 23-day experiments and did not significantly differ from the $\delta^{15} \mathrm{~N}$ of $\mathrm{PN}_{\text {susp }}$ in the lagoon waters where rates of $\mathrm{N}_{2}$ fixation were relatively low and constant in the absence of DIP fertilization (Fig. 1d, Table 1). During P1, $\mathrm{N}_{2}$ fixa- tion added $\sim 0.1 \mu \mathrm{M} \mathrm{N}$ to the mesocosms (Berthelot et al., 2015). Assuming a $\delta^{15} \mathrm{~N}$ of $-1 \%$ o for this DDN (Carpenter et al., 1997; Hoering and Ford, 1960; Minagawa and

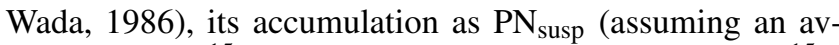
erage $\mathrm{PN}_{\text {susp }} \delta^{15} \mathrm{~N}$ of $3.0 \%$ on day 5) would lower the $\delta^{15} \mathrm{~N}$ of this pool by $\sim 0.4 \%$. However, the $\delta^{15} \mathrm{~N}$ of $\mathrm{PN}_{\text {susp }}$ did not decline and, if anything, increased by day 14 (average $\delta^{15} \mathrm{~N}$ of $3.7 \%$ ), further indicating that DDN did not accumulate significantly in the $\mathrm{PN}_{\text {susp }}$ pool in the mesocosms. This pattern was even more pronounced during P2: while $\mathrm{N}_{2}$ fixation added $\sim 0.25 \mu \mathrm{M} \mathrm{N}$ and the concentration of $\mathrm{PN}_{\text {susp }}$ increased by 0.25 to $0.74 \mu \mathrm{M}$ (Berthelot et al., 2015), the $\delta^{15} \mathrm{~N}$ of $\mathrm{PN}_{\text {susp }}$ remained unchanged (Fig. 1d, Table 1). Thus, while DDN may have passed through the $\mathrm{PN}_{\text {susp }}$ pool, its transit was sufficiently rapid that the $\delta^{15} \mathrm{~N}$ of $\mathrm{N}_{2}$ fixation never accumulated above detection limits in $\mathrm{PN}_{\text {susp }}$.

We note that both the concentration and $\delta^{15} \mathrm{~N}$ of $\mathrm{PN}_{\text {susp }}$ in the lagoon waters were high (i.e., $0.8 \pm 0.1 \mu \mathrm{M}$ and $3.3 \pm 1.3 \%$ ) relative to euphotic zone $\mathrm{PN}_{\text {susp }}$ in similar oligotrophic regions such as near Bermuda and Hawaii (e.g., $\mathrm{PN}_{\text {susp }}$ concentration and $\delta^{15} \mathrm{~N}$ of 0.2 to $0.3 \mu \mathrm{M}$ and -1 to $1 \%$; (Altabet, 1989, 1988; Casciotti et al., 2008; Dore et al., 2002; Fawcett et al., 2011, 2014). The high background $\mathrm{PN}_{\text {susp }}$ concentrations observed in the Noumea lagoon have been previously attributed to anthropogenically driven eutrophication related to untreated sewage release from New Caledonia (Fichez et al., 2010). While the site of the VAHINE mesocosms located $28 \mathrm{~km}$ off the coast was selected to be as representative of the open ocean as possible, it was still at the entrance to the lagoon where the water quality is affected by ocean water inflow, land-derived inputs, and anthropogenic inputs such as industrial and waste water discharge (Labrosse et al., 2000). The high $\delta^{15} \mathrm{~N}$ of $\mathrm{PN}_{\text {susp }}$ may also be at least partly due to this "island effect" as $\mathrm{NO}_{3}^{-}$de- 
riving from human waste is typically high in $\delta^{15} \mathrm{~N}$ (5 to $20 \%$; McClelland and Valiela, 1998; Swart et al., 2013; TownsendSmall et al., 2007). However, subsurface $\mathrm{NO}_{3}^{-} \delta^{15} \mathrm{~N}$ in this region is $6.5 \%$ (this study; Yoshikawa et al., 2015), such that its assimilation by phytoplankton would also serve to elevate

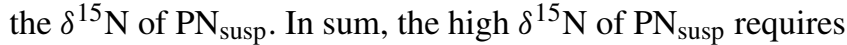
the assimilation of $\mathrm{NO}_{3}^{-}$even if the source of that $\mathrm{NO}_{3}^{-}$is uncertain. More importantly, the invariant $\delta^{15} \mathrm{~N}$ of $\mathrm{PN}_{\text {susp }}$ throughout the mesocosm experiments confirms that while fluxes of DDN may have passed through the $\mathrm{PN}_{\text {susp }}$ pool, DDN did not accumulate as $\mathrm{PN}_{\text {susp }}$ above detection limits. This observation is consistent with previous work showing low seasonality in the $\delta^{15} \mathrm{~N}$ of the $\mathrm{PN}_{\text {susp }}$ pool in spite of changes in the sources and fluxes of new $\mathrm{N}$ to oligotrophic surface waters (e.g., Altabet, 1988).

Similarly, the stability of the DON concentration and $\delta^{15} \mathrm{~N}$ (as well as the consistently low concentrations of $\mathrm{NO}_{3}^{-}+\mathrm{NO}_{2}^{-}$and $\mathrm{NH}_{4}^{+}$; Berthelot et al., 2015) in the mesocosms could be interpreted as indicating that very little DDN was transferred to the dissolved pools during the experiments. These observations are in contrast to previous studies documenting the release of significant quantities of dissolved $\mathrm{N}$ during $\mathrm{N}_{2}$ fixation. For example, elevated DON and/or $\mathrm{NH}_{4}^{+}$concentrations have been observed in the waters surrounding Trichodesmium blooms (Devassy et al., 1978; Karl et al., 1997; Lenes et al., 2001) and in aging Trichodesmium cultures (Mulholland and Capone, 2001), and Trichodesmium has been shown to directly release upwards of $50 \%$ of its newly fixed $\mathrm{N}$ as $\mathrm{DON}$ and/or $\mathrm{NH}_{4}^{+}$(Bonnet et al., 2016a; Capone et al., 1994; Glibert and Bronk, 1994; Mulholland et al., 2004) with a low $\delta^{15} \mathrm{~N}$ (Meador et al., 2007). While the VAHINE mesocosms were dominated by diazotrophs other than Trichodesmium (Turk-Kubo et al., 2015), it is still possible that DDN was released during the experiments but was so rapidly taken up by other (Nlimited) organisms that it never accumulated in the dissolved pool. Indeed, when $\mathrm{N}_{2}$ fixation rates increased towards the end of $\mathrm{P} 1$ and into $\mathrm{P} 2$, diatoms without diazotrophic symbionts rapidly increased 3- to 6-fold in all mesocosms, the non-diazotrophic cyanobacterium, Synechococcus, increased $\sim 10$-fold, and small $(<35 \mu \mathrm{m})$ eukaryotic phytoplankton increased 2- to 4-fold (Leblanc et al., 2016). Given that the mesocosm bags were impermeable to an external physical $\mathrm{N}$ supply (e.g., upwelled or advected $\mathrm{NO}_{3}^{-}$), the most likely $\mathrm{N}$ source fueling the observed phytoplankton growth during P2 was DDN. This is supported by short-term ( 24 to $72 \mathrm{~h}$ ) experiments conducted during the VAHINE study that were designed to track the fate of DDN. They showed the accumulation of ${ }^{15} \mathrm{~N}$ originating from ${ }^{15} \mathrm{~N}_{2}$ fixation in the dissolved $\mathrm{N}$ pool and in the biomass of non-diazotrophic diatoms and picoplankton ( 0.2 to $2 \mu \mathrm{m}$ size fraction) on day 17 and 19 of the mesocosm experiments (Bonnet et al., 2016a). The total $\mathrm{N}$ supplied by $\mathrm{N}_{2}$ fixation during $\mathrm{P} 2$, when $\mathrm{N}_{2}$ fixation rates were highest (average of $27.3 \pm 1.0 \mathrm{nmol} \mathrm{N} \mathrm{L}^{-1} \mathrm{~d}^{-1}$ over the three mesocosms; Berthelot et al., 2015), was $\sim 0.25 \mu \mathrm{M}$. This quantity of $\mathrm{N}$ amounts to $<5 \%$ of the ambient DON concentration, such that the addition of any portion of this DDN to the DON pool, regardless of whether it was subsequently consumed by phytoplankton, would not have been evident above the background DON concentration or $\delta^{15} \mathrm{~N}$. However, it is clear that DDN did not accumulate as $\mathrm{NH}_{4}^{+}$ since, while $\mathrm{NH}_{4}^{+}$concentrations increased slightly during P2 (from $\sim 0.01$ to $0.06 \mu \mathrm{M}$; Berthelot et al., 2015), they were still extremely low throughout the experiments.

In contrast to the invariant $\delta^{15} \mathrm{~N}$ of the $\mathrm{PN}_{\text {susp }}$ and DON pools, the $\delta^{15} \mathrm{~N}$ of $\mathrm{PN}_{\text {sink }}$ significantly decreased over the course of the experiments (Fig. 2a, Table 1). The unique experimental design of the mesocosms provided a closed system that prevented the resupply of nutrients via lateral or vertical exchange, such that $\mathrm{N}_{2}$ fixation is the only new $\mathrm{N}$ source that could drive changes in the $\delta^{15} \mathrm{~N}$ of $\mathrm{PN}_{\text {sink }}$. Moreover, the effectively complete $\mathrm{NO}_{3}^{-}$consumption that occurred in these waters prior to the initiation of the experiments (Berthelot et al., 2015) simplifies $\delta^{15} \mathrm{~N}$ budget calculations by removing the need to consider a potentially variable isotope effect (or indeed, any isotope effect) for $\mathrm{NO}_{3}^{-}$assimilation; only the initial $\delta^{15} \mathrm{~N}$ of the $\mathrm{NO}_{3}^{-}$is required.

We use Eq. (2) to evaluate the contribution of $\mathrm{N}_{2}$ fixation to export production in the mesocosms, taking the $\delta^{15} \mathrm{~N}$ of subsurface $\mathrm{NO}_{3}^{-}$to be that measured in the outside waters that are thought to flush the lagoon $(6.5 \%$ at $200 \mathrm{~m})$. The average fractional contribution of $\mathrm{N}_{2}$ fixation to export production within the three mesocosms increased over the course of the experiments; $\mathrm{N}_{2}$ fixation supported $32 \pm 4,47 \pm 6$, and $56 \pm 24 \%$ of export production during $\mathrm{P} 0, \mathrm{P} 1$, and $\mathrm{P} 2$, respectively (Fig. 2b, Table 1). In spite of the range in $\mathrm{PN}_{\text {sink }}$ $\delta^{15} \mathrm{~N}$, especially in $\mathrm{P} 2$, the mean $\delta^{15} \mathrm{~N}$ of $\mathrm{PN}_{\text {sink }}$ is significantly different between each time period; the fraction of export production supported by $\mathrm{N}_{2}$ fixation during each time period is thus also significantly different. We note that the apparent fractional contribution of $\mathrm{N}_{2}$ fixation to export production suggested by the $\delta^{15} \mathrm{~N}$ of $\mathrm{PN}_{\text {sink }}$ in the VAHINE experiments is high relative to geochemical studies conducted in other tropical and subtropical open ocean regions $(<10$ $25 \%$; Altabet, 1998; Knapp et al., 2005; Casciotti et al., 2008). However, the intentional fertilization of the mesocosms with DIP, the lack of external $\mathrm{N}$ sources other than $\mathrm{N}_{2}$ fixation to the water column, and the $15 \mathrm{~m}$ mesocosm water column that was both significantly shallower and less turbulent than that of the open ocean study sites, all likely favored diazotrophy in the mesocosms. Direct comparison of the fractional significance of $\mathrm{N}_{2}$ fixation to export production in the VAHINE experiments with observations from open ocean sites should thus be made with caution.

Given the potential for especially large gradients in the $\delta^{15} \mathrm{~N}$ of $\mathrm{NO}_{3}^{-}$in the upper thermocline of the South Pacific (Casciotti et al., 2013; Yoshikawa et al., 2015), and the possibility that the island provided a source of $\mathrm{NO}_{3}^{-}$of unknown 
Table 2. Comparison of time-integrated diazotroph derived $\mathrm{N}$ (DDN) for each mesocosm based on $\delta^{15} \mathrm{~N}$ budget calculations and ${ }^{15} \mathrm{~N}_{2}$ fixation incubation rates.

\begin{tabular}{lrrr}
\hline & M1 & M2 & M3 \\
\hline$\delta^{15} \mathrm{~N}$ budget DDN $(\mu \mathrm{M})$ & 0.29 & 0.28 & 0.20 \\
${ }^{15} \mathrm{~N}_{2}$ incubation $[\mathrm{N}](\mu \mathrm{M})$ & 0.41 & 0.38 & 0.38 \\
$\delta{ }^{15} \mathrm{~N}$ budget $/{ }^{15} \mathrm{~N}_{2}$ incubation & $71 \%$ & $75 \%$ & $52 \%$ \\
\hline
\end{tabular}

(albeit high) $\delta^{15} \mathrm{~N}$ to the lagoon, the results of our $\delta^{15} \mathrm{~N}$ budget are best used to evaluate relative changes in the sources of $\mathrm{N}$ fueling export production. Regardless of the uncertainty in the absolute contribution of $\mathrm{N}_{2}$ fixation to export production at any one time point, the relative shift in the $\delta^{15} \mathrm{~N}$ of $\mathrm{PN}_{\text {sink }}$ is significant and clearly indicates that export production in the mesocosms was initially fueled primarily by $\mathrm{NO}_{3}^{-}$ that had been assimilated prior to the start of the experiments, with $\mathrm{N}_{2}$ fixation becoming the dominant driver of export by the end of the experiments.

During P0, the rates of primary production and $\mathrm{N}_{2}$ fixation were low, although $\mathrm{N}_{2}$ fixation appears to have been slightly higher than during P1 (Berthelot et al., 2015). In addition, there was no observable increase in $\mathrm{PN}_{\text {susp }}$ concentration during P1, indicating that little to no growth occurred during this phase of the experiments. Given the mean $\mathrm{PN}_{\text {sink }} \delta^{15} \mathrm{~N}$ of $4.1 \pm 0.3 \%$ o during P0, we hypothesize that the sinking flux (which was also low; $\sim 0.07 \mathrm{mmol} \mathrm{N} \mathrm{m}^{-2} \mathrm{~d}^{-1}$; Fig. 2a) likely constituted mainly large cells that, due to the lack of nutrients and turbulence that characterized the mesocosm enclosures, were unable to grow and instead sank rapidly out of surface waters. This is supported by the following: (i) a small but detectable decline in the concentration of $\mathrm{PC}_{\text {susp }}$ during P0 (Berthelot et al., 2015); (ii) taxonomy data from the mesocosms showing a sharp decline in the abundance of the initially dominant, large and chain-forming diatom species (e.g., Thalassionema spp., Leptocylindrus spp., and Chaetoceros spp.) between days 2 and 5 (Leblanc et al., 2016), and (iii) calculations using Stokes' law, modified specifically for diatoms by (Miklasz and Denny, 2010), that predict that diatoms with a diameter of 50 to $100 \mu \mathrm{m}$ will sink at speeds $>10 \mathrm{~m} \mathrm{day}^{-1}$, allowing them to easily sink out of the $15 \mathrm{~m}$-deep mesocosms on the timescale of a day. Given that diatoms have a strong tendency towards $\mathrm{NO}_{3}^{-}$assimilation (Dortch, 1990; Fawcett and Ward, 2011; Goericke, 2002), the preferential sinking out of large diatoms that had consumed predominantly $\mathrm{NO}_{3}^{-}$prior to the commencement of the experiments can explain the slightly higher $\delta^{15} \mathrm{~N}$ of $\mathrm{PN}_{\text {sink }}$ during P0 than P1 (average of $4.1 \pm 0.3 \%$ vs. $3.0 \pm 0.4 \%$ ), even though $\mathrm{N}_{2}$ fixation was marginally higher during $\mathrm{P} 0$.

Throughout most of $\mathrm{P} 1, \mathrm{~N}_{2}$ fixation rates, primary production, and the sinking flux remained low and constant (Berthelot et al., 2015; Fig. 2a). Along with the relatively invariant $\delta^{15} \mathrm{~N}$ of $\mathrm{PN}_{\text {sink }}$ during this period, these observations suggest that $\mathrm{PN}_{\text {sink }}$ comprised mostly aggregated suspended material that had been present in surface waters since the beginning of the experiments rather than newly generated biomass. Indeed, the $\delta^{15} \mathrm{~N}$ of $\mathrm{PN}_{\text {sink }}$ throughout $\mathrm{P} 1$ is indistinguishable from that of $\mathrm{PN}_{\text {susp }}(3 \%$; Figs. 1d and 2a, Table 1). Thus, despite the lack of $\mathrm{NO}_{3}^{-}$in the mesocosms, more than half of the export production that occurred during $\mathrm{P} 1$ was supported by $\mathrm{NO}_{3}^{-}$that had been assimilated by phytoplankton prior to the start of the experiments (Eq. 1). $\mathrm{N}_{2}$ fixation rates began to increase by day 11 or 12 in all mesocosms; this was quickly followed by an increase in $\mathrm{PN}_{\text {susp }}$ concentrations, as well as an increase in the magnitude of the sinking flux and a decrease in its $\delta^{15} \mathrm{~N}$, consistent with both an increased supply of $\mathrm{N}$ to the mesocosms and a low $\delta^{15} \mathrm{~N}$ for that $\mathrm{N}$.

To confirm that the decrease in the $\delta^{15} \mathrm{~N}$ of $\mathrm{PN}_{\text {sink }}$ is best explained by $\mathrm{N}_{2}$ fixation, we compared the $\mathrm{N}_{2}$ fixation rate derived from the $\delta^{15} \mathrm{~N}$ budget (Eqs. (1) and (2), above) with the ${ }^{15} \mathrm{~N}_{2}$ incubation-based $\mathrm{N}_{2}$ fixation rates (Berthelot et al., 2015; Table 2). The time-integrated DDN that accumulated as $\mathrm{PN}_{\text {sink }}$ over the course of the 23-day experiments in each of the mesocosms corresponds to 52 to $75 \%$ of the ${ }^{15} \mathrm{~N}_{2}$ incubation-based $\mathrm{N}_{2}$ fixation flux integrated over the same time period (Table 2). In spite of the uncertainty associated with both analyses, including the different timescales over which each metric may integrate $\mathrm{N}_{2}$ fixation fluxes and the possibility that some of the DDN accumulated in the DON and/or $\mathrm{PN}_{\text {susp }}$ pools below analytical detection limits, we conclude that the primary fate of newly fixed $\mathrm{N}$ in the VAHINE mesocosm experiments was to be converted into the $\mathrm{PN}_{\text {sink }}$ flux.

We note that the net DON consumption at the end of P2 proposed by (Berthelot et al., 2015) would not change our $\delta^{15} \mathrm{~N}$ budgets given the suggestion by the authors that the primary fate of this DON was to accumulate in the $\mathrm{PN}_{\text {susp }}$ pool; this represents a redistribution of $\mathrm{N}$ between surface pools separate from the $\mathrm{PN}_{\text {sink }}$ flux. While there is no reason that the consumed DON had to be retained in the $\mathrm{PN}_{\text {susp }}$ pool, the isotopic data indicate that if the (Berthelot et al., 2015) DON concentrations are correct, then, as the authors propose, the fate of this DON has to primarily be retention in the $\mathrm{PN}_{\text {susp }}$ pool. The isotope data also suggest that the majority of the DDN in the mesocosms was fairly rapidly exported, either directly by sinking diazotrophs, by zooplankton grazing upon the diazotrophs (Hunt et al., 2016), and/or indirectly after being cycled through the dissolved $\mathrm{N}$ pool and assimilated by non-diazotrophic plankton in the $\mathrm{PN}_{\text {susp }}$ pool that then sank into the sediment traps (Bonnet et al., 2016a), rather than being retained in surface waters. This is consistent with prior work using $\delta^{15} \mathrm{~N}$ budgets to quantify the significance of DDN for supporting export production (Altabet, 1988; Casciotti et al., 2008; Dore et al., 2002). The results presented here demonstrate that the $\delta^{15} \mathrm{~N}$ of the $\mathrm{PN}_{\text {sink }}$ flux, compared to the $\delta^{15} \mathrm{~N}$ of DON and/or the $\mathrm{PN}_{\text {susp }}$ pool, is the most appropriate tool for evaluating the fate of newly fixed $\mathrm{N}$ on timescales ranging from 1 day to several weeks 
because it records the $\delta^{15} \mathrm{~N}$ of the sources of new $\mathrm{N}$ fueling export production with the most fidelity.

\section{2 $\mathrm{NO}_{3}^{-}$- and $\mathrm{N}_{2}$ fixation-driven export production in the context of changing phytoplankton and diazotroph community composition}

The shift from $\mathrm{NO}_{3}^{-}$to $\mathrm{N}_{2}$ fixation as the dominant source of $\mathrm{N}$ fueling export production during the VAHINE mesocosm experiments is paralleled by observed changes in the composition of the phytoplankton and diazotroph communities (Leblanc et al., 2016; Turk-Kubo et al., 2015). In particular, the diazotroph that dominated inside the mesocosms prior to DIP fertilization (i.e., during P0), as well as immediately following DIP fertilization (i.e., during P1), was Richelia associated with the diatom Rhizosolenia (Het-1), a diatom-diazotroph assemblage (DDA) that was also common in the Noumea lagoon waters (Turk-Kubo et al., 2015). However, a Cyanothece-like group-C unicellular cyanobacterial diazotroph (hereafter, "UCYN-C") came to dominate the diazotroph community inside the mesocosms during P2. This diazotroph was rarely observed outside the mesocosms, suggesting that the experiment itself created favorable conditions for the success of this ecotype, which has never been observed at high abundances in the marine water column (Turk-Kubo et al., 2015). It is possible that the microbial community response to DIP fertilization created conditions suitable for UCYN-C growth inside the mesocosms (see below; Turk-Kubo et al., 2015).

During P0, the diatom community was numerically dominated by non-diazotrophic species such as Leptocylindrus spp. and Chaetoceros spp., with DDAs comprising a minor fraction (i.e., $<5 \%$ ) of total diatom abundance, and becoming even less abundant during P1 (Leblanc et al., 2016). Thus, while DDAs may have been responsible for the low levels of $\mathrm{N}_{2}$ fixation detected during P0 and P1, they were not sufficiently abundant to be important drivers of export production; rather, we suggest that the small amount of export that occurred during P0 and P1 was fueled by large (non-DDA) diatoms and aggregating $\mathrm{PN}_{\text {susp }}$ that bore the high $\delta^{15} \mathrm{~N}$ of earlier $\mathrm{NO}_{3}^{-}$consumption (see above).

The increase in the rate of $\mathrm{N}_{2}$ fixation observed towards the end of P1 (days 11 to 12) was rapidly followed by a 2- to 10-fold increase in the abundance of nondiazotrophic diatoms, driven almost exclusively by Cylindrotheca closterium, which reached maximum abundance on days 15 to 16 and then declined to P1 levels by days 18 to 20 (Leblanc et al., 2016). Beginning on day 11 to 15 , the abundance of both Synechococcus and small eukaryotic phytoplankton $(<35 \mu \mathrm{m})$ also increased, although less rapidly than the diatoms. Unlike the large diatoms, these two groups continued to grow until the end of the experiments (Leblanc et al., 2016). Molecular data suggest that UCYN-C were the dominant diazotrophs responsible for the elevated rates of $\mathrm{N}_{2}$ fixation during late $\mathrm{P} 1$ and throughout $\mathrm{P} 2$ (Turk-
Kubo et al., 2015). We hypothesize that the subsequent rapid transfer of DDN to the dissolved pool fueled the observed growth of $C$. closterium and other phytoplankton during this time period. This is supported by a short-term ${ }^{15} \mathrm{~N}_{2}$ labeledDDN transfer experiment conducted on days 17 and 19 in which nanoSIMS (nanoscale secondary ion mass spectrometry) analyses revealed that non-diazotrophic plankton (diatoms and picoplankton) became significantly enriched in ${ }^{15} \mathrm{~N}$ after 24 to $72 \mathrm{~h}$ due to their assimilation of DDN transferred from the diazotrophs in the mesocosms (Bonnet et al., 2016a). Regardless of the form of this DDN (i.e., $\mathrm{NH}_{4}^{+}$or DON), in the mesocosms it would retain the low- $\delta^{15} \mathrm{~N}$ characteristic of $\mathrm{N}_{2}$ fixation, thereby lowering the $\delta^{15} \mathrm{~N}$ of the phytoplankton that consumed it. Since the $\delta^{15} \mathrm{~N}$ of $\mathrm{PN}_{\text {susp }}$ did not decline significantly during $\mathrm{P} 2$ but the $\delta^{15} \mathrm{~N}$ of $\mathrm{PN}_{\text {sink }}$ did, it follows that the sinking flux likely comprised a contribution from both UCYN-C and the DDN-fueled phytoplankton. The isotope data also suggest that while the $C$. closterium and other phytoplankton that consumed the DDN may have briefly contributed to the $\mathrm{PN}_{\text {susp }}$ pool, they did not accumulate above detection limits in the $\mathrm{PN}_{\text {susp }}$ pool for $>1$ day (i.e., the timescale of mesocosm sampling) before sinking. This is analogous to the DDN passing briefly and undetectably through the dissolved $\mathrm{N}$ pool before it was rapidly consumed by phytoplankton. UCYN-C are small cyanobacteria $(5.7 \pm 0.8 \mu \mathrm{m})$; (Bonnet et al., 2016a), but they were observed to aggregate into 100 to $500 \mu \mathrm{m}$ particles that sank rapidly, constituting $22.4 \pm 5 \%$ of the $\mathrm{PC}_{\text {sink }}$ flux at the height of the UCYN-C bloom (day 17) and $\sim 5 \%$ as the bloom decayed (Bonnet et al., 2016a). In addition to their direct contribution to export, UCYN-C provided the $\mathrm{N}$ that fueled phytoplankton growth during $\mathrm{P} 2$, such that this organism was responsible for driving most of export production in the mesocosms, albeit largely indirectly. One implication of these results is that the phenomenon of newly fixed $\mathrm{N}$ being released to the dissolved pool is apparently not unique to Trichodesmium spp. Another implication of the indirect control of diazotrophs on export production, if relevant to the open ocean, is that while the transfer of DDN to depth via non-diazotrophic phytoplankton ultimately leads to a decline in the $\delta^{15} \mathrm{~N}$ of thermocline $\mathrm{NO}_{3}^{-}$, it will not increase the $\mathrm{NO}_{3}^{-}: \mathrm{PO}_{4}^{3-}$ concentration ratio of these subsurface waters.

\section{Conclusions}

The goal of the VAHINE project was to track the fate of newly fixed $\mathrm{N}$ in large-volume, DIP-fertilized mesocosm experiments. Consistent with previous work, we found no evidence of newly fixed $\mathrm{N}$ accumulating in the surface DON or $\mathrm{PN}_{\text {susp }}$ pools. Instead, the $\delta^{15} \mathrm{~N}$ of the $\mathrm{PN}_{\text {sink }}$ flux decreased over the course of the experiments in proportion to increasing rates of $\mathrm{N}_{2}$ fixation. These observations are consistent with the traditional oceanographic paradigm that new fluxes of $\mathrm{N}$ to the surface ocean are balanced by the dom- 
inant flux out of surface waters, the sinking particulate flux (Eppley and Peterson, 1979). Moreover, they suggest that upper ocean $\delta^{15} \mathrm{~N}$ budgets that include measurements of $\mathrm{PN}_{\text {sink }}$ are the best metric for tracking the fate of DDN and for diagnosing the dominant $\mathrm{N}$ source fueling export production. While at-sea collections of $\mathrm{PN}_{\text {sink }}$ are expensive and logistically challenging, our results underscore the value of $\mathrm{PN}_{\text {sink }}$ $\delta^{15} \mathrm{~N}$ measurements and emphasize their critical role in constraining the location, magnitude, and timing of marine $\mathrm{N}_{2}$ fixation fluxes.

This work provides isotopic evidence not only for newly fixed $\mathrm{N}$ leaving surface waters via the sinking flux, but also strongly suggests that DDN was first rapidly cycled through the dissolved $\mathrm{N}$ and $\mathrm{PN}_{\text {susp }}$ pools before being transferred to the sinking flux. While prior $\delta^{15} \mathrm{~N}$ budget studies have shown the rapid transfer of low- $\delta^{15} \mathrm{~N} \mathrm{~N}$ from surface to subsurface waters, the unique design of the mesocosm experiments that received no other external $\mathrm{N}$ source to support phytoplankton growth after several weeks of isolation requires that the low$\delta^{15} \mathrm{~N} \mathrm{PN}_{\text {sink }}$ flux observed during P2 was fueled by DDN. Daily water column measurements of dissolved organic and inorganic $\mathrm{N}$ concentrations (and the $\delta^{15} \mathrm{~N}$ of DON) indicate that DDN did not accumulate above detection limits in these or the $\mathrm{PN}_{\text {susp }}$ pools for $>1$ day timescales. While the $\delta^{15} \mathrm{~N}$ budget suggests that $\mathrm{N}_{2}$ fixation was the primary source of $\mathrm{N}$ fueling export production during $\mathrm{P} 2$, phytoplankton abundance data show that non-diazotrophic phytoplankton, including large diatoms and Synechococcus, "bloomed" during P2 (Leblanc et al., 2016), accumulating in numbers too large to be supported by recycled forms of $\mathrm{N}$ that did not derive from $\mathrm{N}_{2}$ fixation. Assuming that these non-diazotrophic phytoplankton had no other means of acquiring $\mathrm{N}$ than via the UCYN-C population that also increased significantly during P2, it is extremely likely that DDN was transferred from UCYN-C to the non-diazotrophic phytoplankton that drove most of the export production, along with a small direct contribution ( $\sim 5$ to $22 \%$ ) from aggregated UCYN-C cells (Bonnet et al., 2016a) and zooplankton grazing (Hunt et al., 2016). Indeed, such a DDN transfer to the non-diazotrophic pool was directly observed in a companion nanoSIMS $-{ }^{15} \mathrm{~N}_{2}$ study conducted in mid-P2 when UCYN-C was blooming but diatom abundances were declining (Bonnet et al., 2016a); there is no reason that the same mechanism did not fuel the growth of diatoms earlier in P2. These diatoms included C. closterium, which reportedly has the ability to survive in low nutrient environments with seed populations that remain poised to thrive when supplied with a pulse of nutrients, and then sink out of surface waters under calm conditions due to their size (Kingston, 2009; Margalef, 1978; Wasmund et al., 2014). This is consistent with our observations of $\mathrm{PN}_{\text {susp }}$ and $\mathrm{PN}_{\text {sink }}$ during the VAHINE experiments. In addition, $C$. closterium abundances have been observed to increase dramatically after Trichodesmium blooms in the South West Pacific (Bonnet et al., 2016). Our study provides some of the first evidence for DDN being rapidly transferred through the dissolved pool to other phytoplankton that then dominate the sinking flux instead of being transferred to the subsurface by diazotrophs sinking directly out of surface waters.

Our findings are consistent with prior work showing that diazotrophs release newly fixed $\mathrm{N}$ to the dissolved pool (Capone et al., 1994; Glibert and Bronk, 1994; Mulholland et al., 2004, 2006), as well as with studies that have failed to observe DDN accumulating in surface ocean N pools (Fawcett et al., 2011, 2014; Knapp et al., 2005, 2011). The results of the VAHINE experiments reconcile some of these observations, but also leave open the question of the composition of the DDN that is released to the dissolved pool. Additionally, the experiments raise the questions of how microbes and phytoplankton stay "poised" to rapidly assimilate DDN, and why they sink out of surface waters when they acquire DDN, with no retention or accumulation of that DDN in the upper ocean $\mathrm{N}$ pools. In other words, why is the fate of DDN so disproportionately biased towards sinking?

\section{Information about the Supplement}

All data generated for this manuscript are available in the Supplement related to this article.

\section{The Supplement related to this article is available online at doi:10.5194/bg-13-4645-2016-supplement.}

Acknowledgements. We acknowledge the input of Travis Meador and two anonymous reviewers that clarified the manuscript. Funding for Angela N. Knapp was provided by NSF-OCE \#1537314, for Sarah E. Fawcett from the University of Cape Town URC fund, the Grand Challenges Program of Princeton University, and NSF-OCE \#1136345 to B. Ward and D. Sigman. Funding for this research was provided by the Agence Nationale de la Recherche (starting grant VAHINE ANR-13-JS06-0002), INSU-LEFE-CYBER program, GOPS, IRD and M.I.O. The authors thank the captain and crew of the R/V Alis and acknowledge the SEOH divers service from the IRD research center of Noumea (E. Folcher, B. Bourgeois, and A. Renaud) and from the Observatoire Océanologique de Villefranche-sur-mer (OOV, J. M. Grisoni) as well as the technical service of the IRD research center of Noumea for their helpful technical support. C. Guieu, F. Louis, and J. M. Grisoni from OOV are warmly thanked for the mesocosm design and their useful advice for deployment. The authors also thank D. Sigman and G. Haug for providing analytical support for $\mathrm{N}$ concentration and isotope measurements.

Edited by: F. Lacan

Reviewed by: T. B. Meador and two anonymous referees 


\section{References}

Altabet, M. A.: Particulate New Nitrogen Fluxes in the Sargasso Sea, J. Geophys. Res.-Oceans, 94, 12771-12779, 1989.

Altabet, M. A.: Variations in Nitrogen Isotopic Composition between Sinking and Suspended Particles - Implications for Nitrogen Cycling and Particle Transformation in the Open Ocean, Deep-Sea Res. Pt. I, 35, 535-554, 1988.

Altabet, M. A. and McCarthy, J. J.: Temporal and Spatial Variations in the Natural Abundance of N-15 in PON from a Warm-Core Ring, Deep-Sea Res. Pt. I, 32, 755-772, 1985.

Benner, R.: Chemical Composition and Reactivity, in: Biogeochemistry of Marine Dissolved Organic Matter, edited by: Hansell, D. A. and Carlson, C. A., Academic Press, New York, 2002.

Berman-Frank, I., Bidle, K. D., Haramaty, L., and Falkowski, P. G.: The demise of the marine cyanobacterium, Trichodesmium spp., via an autocatalyzed cell death pathway, Limnol. Oceanogr., 49, 997-1005, 2004.

Berthelot, H., Moutin, T., L'Helguen, S., Leblanc, K., Hélias, S., Grosso, O., Leblond, N., Charrière, B., and Bonnet, S.: Dinitrogen fixation and dissolved organic nitrogen fueled primary production and particulate export during the VAHINE mesocosm experiment (New Caledonia lagoon), Biogeosciences, 12, 40994112, doi:10.5194/bg-12-4099-2015, 2015.

Bonnet, S., Berthelot, H., Turk-Kubo, K., Fawcett, S., Rahav, E., L'Helguen, S., and Berman-Frank, I.: Dynamics of $\mathrm{N}_{2}$ fixation and fate of diazotroph-derived nitrogen in a low-nutrient, low-chlorophyll ecosystem: results from the VAHINE mesocosm experiment (New Caledonia), Biogeosciences, 13, 2653-2673, doi:10.5194/bg-13-2653-2016, 2016a.

Bonnet, S., Moutin, T., Rodier, M., Grisoni, J.-M., Louis, F., Folcher, E., Bourgeois, B., Boré, J.-M., and Renaud, A.: Introduction to the project VAHINE: VAriability of vertical and tropHIc transfer of diazotroph derived $\mathrm{N}$ in the south wEst Pacific, Biogeosciences, 13, 2803-2814, doi:10.5194/bg-13-28032016, 2016b.

Bonnet, S., Rodier, M., Turk-Kubo, K. A., Germineaud, C., Menkes, C., Ganachaud, A., Cravatte, S., Raimbault, P., Campbell, E., Quéroué, F., Sarthou, G., Desnues, A., Maes, C., and Eldin, G.: Contrasted geographical distribution of $\mathrm{N}_{2}$ fixation rates and nifH phylotypes in the Coral and Solomon Seas (southwestern Pacific) during austral winter conditions, Global Biogeochem. Cy., 29, doi:10.1002/2015GB005117, 2015.

Braman, R. S. and Hendrix, S. A.: Nanogram Nitrite and Nitrate Determination in Environmental and Biological-Materials by Vanadium(III) Reduction with Chemi-Luminescence Detection, Anal. Chem., 61, 2715-2718, 1989.

Capone, D. G., Burns, J. A., Montoya, J. P., Subramaniam, A., Mahaffey, C., Gunderson, T., Michaels, A. F., and Carpenter, E. J.: Nitrogen fixation by Trichodesmium spp.: An important source of new nitrogen to the tropical and subtropical North Atlantic Ocean, Global Biogeochem. Cy., 19, doi:10.1029/2004GB002331, 2005.

Capone, D. G., Ferrier, M. D., and Carpenter, E. J.: AminoAcid Cycling in Colonies of the Planktonic Marine Cyanobacterium Trichodesmium-Thiebautii, Appl. Environ. Microbiol., 60, 3989-3995, 1994.

Carpenter, E. J., Harvey, H. R., Fry, B., and Capone, D. G.: Biogeochemical tracers of the marine cyanobacterium Trichodesmium, Deep-Sea Res. Pt. I, 44, 27-38, 1997.
Casciotti, K. L., Buchwald, C., and McIlvin, M.: Implications of nitrate and nitrite isotopic measurements for the mechanisms of nitrogen cycling in the Peru oxygen deficient zone, Deep-Sea Res. Pt. I, 80, 78-93, 2013.

Casciotti, K. L., Sigman, D. M., Hastings, M. G., Bohlke, J. K., and Hilkert, A.: Measurement of the oxygen isotopic composition of nitrate in seawater and freshwater using the denitrifier method, Anal. Chem., 74, 4905-4912, 2002.

Casciotti, K. L., Trull, T. W., Glover, D. M., and Davies, D.: Constraints on nitrogen cycling at the subtropical North Pacific Station ALOHA from isotopic measurements of nitrate and particulate nitrogen, Deep-Sea Res. Pt. II, 55, 1661-1672, 2008.

Deutsch, C., Gruber, N., Key, R. M., Sarmiento, J. L., and Ganachaud, A.: Denitrification and N(2) fixation in the Pacific Ocean, Global Biogeochem. Cy., 15, 483-506, 2001.

Devassy, V. P., Bhattathiri, P. M. A., and Qasim, S. Z.: Trichodesmium-erythraeum phenomenon, Indian J. Mar. Sci., 7, 168-186, 1978.

Dore, J. E., Brum, J. R., Tupas, L. M., and Karl, D. M.: Seasonal and interannual variability in sources of nitrogen supporting export in the oligotrophic subtropical North Pacific Ocean, Limnol. Oceanogr., 47, 1595-1607, 2002.

Dortch, Q.: The interaction between ammonium and nitrate uptake in phytoplankton, Mar. Ecol.-Prog. Ser., 61, 183-201, 1990.

Dupouy, C., Neveux, J., Subramaniam, A., Mulholland, M. R., Montoya, J. P., Campbell, L., Carpenter, E. J., and Capone, D. G.: Satellite captures Trichodesmium blooms in the southwestern tropical Pacific, EOS, 81, 13-16, 2000.

Eppley, R. W. and Peterson, B. J.: Particulate organic-matter flux and planktonic new production in the deep ocean, Nature, 282 677-680, 1979.

Eugster, O. and Gruber, N.: A probabilistic estimate of global marine $\mathrm{N}$-fixation and denitrification, Global Biogeochem. Cy., 26, GB4013, doi:10.1029/2012GB004300, 2012.

Falkowski, P. G.: Evolution of the nitrogen cycle and its influence on the biological sequestration of $\mathrm{CO}_{2}$ in the ocean, Nature, 387, 272-275, 1997.

Falkowski, P. G.: Rationalizing elemental ratios in unicellular algae, J. Phycol., 36, 3-6, 2000.

Fawcett, S. and Ward, B.: Phytoplankton succession and nitrogen utilization during the development of an upwelling bloom, Mar. Ecol.-Prog. Ser., 428, 13-31, 2011.

Fawcett, S. E., Lomas, M., Casey, J. R., Ward, B. B., and Sigman, D. M.: Assimilation of upwelled nitrate by small eukaryotes in the Sargasso Sea, Nat. Geosci., 4, 717-722, 2011.

Fawcett, S. E., Lomas, M. W., Ward, B. B., and Sigman, D. M.: The counterintuitive effect of summer-to-fall mixed layer deepening on eukaryotic new production in the Sargasso Sea, Global Biogeochem. Cy., 28, 86-102, 2014.

Fichez, R., Chifflet, S., Douillet, P., Gérard, P., Gutierrez, F., Jouon, A., Ouillon, S., and Grenz, C.: Biogeochemical typology and temporal variability of lagoon waters in a coral reef ecosystem subject to terrigeneous and anthropogenic inputs (New Caledonia), Mar. Pollut. Bull., 61, 309-322, 2010.

Glibert, P. M. and Bronk, D. A.: Release of Dissolved Organic Nitrogen by Marine Diazotrophic Cyanobacteria, Trichodesmium Spp, Appl. Environ. Microbiol., 60, 3996-4000, 1994. 
Goericke, R.: Top-down control of phytoplankton biomass and community structure in the monsoonal Arabian Sea, Limnol. Oceanogr., 47, 1307-1323, 2002.

Gruber, N.: The dynamics of the marine nitrogen cycle and its influence on atmospheric $\mathrm{CO}_{2}$ variations, in: The Ocean Carbon Cycle and Climate, Follows, edited by: Follows, M. and Oguz, T., Kluwer Academic, Dordrecht, 2004.

Gruber, N. and Sarmiento, J. L.: Global patterns of marine nitrogen fixation and denitrification, Global Biogeochem. Cy., 11, 235266, 1997.

Hansell, D. A., Bates, N. R., and Olson, D. B.: Excess nitrate and nitrogen fixation in the North Atlantic Ocean, Mar. Chem., 84, 243-265, 2004.

Higgins, M. B., Robinson, R. S., Casciotti, K. L., McIlvin, M. R., and Pearson, A.: A Method for Determining the Nitrogen Isotopic Composition of Porphyrins, Anal. Chem., 81, 184-192, 2009.

Hoering, T. C. and Ford, H. T.: The Isotope Effect in the Fixation of Nitrogen by Azotobacter, J. Am. Chem. Soc., 82, 376-378, 1960.

Holl, C. M. and Montoya, J. P.: Diazotrophic growth of the marine cyanobacterium Trichodesmium IMS101 in continuous culture: Effects of growth rate on $\mathrm{N}(2)$-fixation rate, biomass, and C : N : P stoichiometry, J. Phycol. 44, 929-937, 2008.

Holmes, R. M., Aminot, A., Kerouel, R., Hooker, B. A., and Peterson, B. J.: A simple and precise method for measuring ammonium in marine and freshwater ecosystems, Can J. Fish. Aquat. Sci., 56, 1801-1808, 1999.

Hunt, B. P. V., Bonnet, S., Berthelot, H., Conroy, B. J., Foster, R. A., and Pagano, M.: Contribution and pathways of diazotrophderived nitrogen to zooplankton during the VAHINE mesocosm experiment in the oligotrophic New Caledonia lagoon, Biogeosciences, 13, 3131-3145, doi:10.5194/bg-13-3131-2016, 2016.

Karl, D., Letelier, R., Tupas, L., Dore, J., Christian, J., and Hebel, D.: The role of nitrogen fixation in biogeochemical cycling in the subtropical North Pacific Ocean, Nature, 388, 533-538, 1997.

Kingston, M. B.: Growth and motility of the diatom Cylindrotheca Closterium: Implications for commercial applications, Journal of the North Carolina Academy of Science, 125, 138-142, 2009.

Knapp, A. N., Casciotti, K. L., Berelson, W. M., Prokopenko, M. G., and Capone, D. G.: Low rates of nitrogen fixation in eastern tropical South Pacific surface waters, P. Natl. Acad. Sci. USA, 113, 4398-4403, 2016.

Knapp, A. N., DiFiore, P. J., Deutsch, C., Sigman, D. M., and Lipschultz, F.: Nitrate isotopic composition between Bermuda and Puerto Rico: Implications for N(2) fixation in the Atlantic Ocean, Global Biogeochem. Cy., 22, doi:10.1029/2007GB003107, 2008.

Knapp, A. N., Sigman, D. M., and Lipschultz, F.: N isotopic composition of dissolved organic nitrogen and nitrate at the Bermuda Atlantic time-series study site, Global Biogeochem. Cy., 19, doi:10.1029/2004GB002320, 2005.

Knapp, A. N., Sigman, D. M., Lipschultz, F., Kustka, A. B., and Capone, D. G.: Interbasin isotopic correspondence between upper-ocean bulk DON and subsurface nitrate and its implications for marine nitrogen cycling, Global Biogeochem. Cy., 25, doi:10.1029/2010GB003878, 2011.

Krauk, J. M., Villareal, T. A., Sohm, J. A., Montoya, J. P., and Capone, D. G.: Plasticity of $\mathrm{N}$ : $\mathrm{P}$ ratios in laboratory and field populations of Trichodesmium spp, Aquat. Microb. Ecol., 42, 243-253, 2006.

Kustka, A. B., Sanudo-Wilhelmy, S. A., Carpenter, E. J., Capone, D., Burns, J., and Sunda, W. G.: Iron requirements for dinitrogenand ammonium-supported growth in cultures of Trichodesmium (IMS 101): Comparison with nitrogen fixation rates and iron: carbon ratios of field populations, Limnol. Oceanogr., 48, 18691884, 2003.

Labrosse, P., Fichez, R., Farman, R., and Adams, T.: New Caledonia, in: Seas at the Millenium, An Environmental Evaluation, edited by: Sheppard, C., Elsevier, Amsterdam, 2000.

Leblanc, K., Cornet, V., Caffin, M., Rodier, M., Desnues, A., Berthelot, H., Turk-Kubo, K., and Heliou, J.: Phytoplankton community structure in the VAHINE MESOCOSM experiment, Biogeosciences Discuss., doi:10.5194/bg-2015-605, in review, 2016.

Lenes, J. M., Darrow, B. P., Cattrall, C., Heil, C. A., Callahan, M., Vargo, G. A., Byrne, R. H., Prospero, J. M., Bates, D. E., Fanning, K. A., and Walsh, J. J.: Iron fertilization and the Trichodesmium response on the West Florida shelf, Limnol. Oceanogr., 46, 1261-1277, 2001.

Letscher, R. T., Hansell, D. A., Carlson, C. A., Lumpkin, R., and Knapp, A. N.: Dissolved organic nitrogen in the global surface ocean: Distribution and fate, Global Biogeochem. Cy., 27, 141153, 2013.

Liu, K. K., Su, M. J., Hsueh, C. R., and Gong, G. C.: The nitrogen isotopic composition of nitrate in the Kuroshio Water northeast of Taiwan: Evidence for nitrogen fixation as a source of isotopically light nitrate, Mar. Chem., 54, 273-292, 1996.

Lourey, M. J., Trull, T. W., and Sigman, D. M.: Sensitivity of delta $\mathrm{N}-15$ of nitrate, surface suspended and deep sinking particulate nitrogen to seasonal nitrate depletion in the Southern Ocean, Global Biogeochem. Cy., 17, doi:10.1029/2002GB001973, 2003.

Margalef, R.: Life-forms of phytoplankton as survival alternatives in an unsustainable environment, Oceanol. Ac., 1, 493-509, 1978.

McClelland, J. W. and Valiela, I.: Linking nitrogen in estuarine producers to land-derived sources, Limnol. Oceanogr., 43, 577-585, 1998.

McIlvin, M. R. and Casciotti, K. L.: Technical Updates to the Bacterial Method for Nitrate Isotopic Analyses, Anal. Chem., 83, 1850-1856, 2011

Meador, T. B., Aluwihare, L. I., and Mahaffey, C.: Isotopic heterogeneity and cycling of organic nitrogen in the oligotrophic ocean, Limnol. Oceanogr., 52, 934-947, 2007.

Miklasz, K. A. and Denny, M. W.: Diatom sinking speeds: Improved predictions and insight from a modified Stokes' law, Limnol. Oceanogr., 55, 2513-2525, 2010.

Minagawa, M. and Wada, E.: Nitrogen Isotope Ratios of Red Tide Organisms in the East-China-Sea - a Characterization of Biological Nitrogen-Fixation, Mar. Chem., 19, 245-259, 1986.

Montoya, J. P., Holl, C. M., Zehr, J. P., Hansen, A., Villareal, T. A., and Capone, D. G.: High rates of $\mathrm{N}_{2}$ fixation by unicellular diazotrophs in the oligotrophic Pacific Ocean, Nature, 430, 1027-1031, 2004

Moutin, T., Karl, D. M., Duhamel, S., Rimmelin, P., Raimbault, P., Van Mooy, B. A. S., and Claustre, H.: Phosphate availability and the ultimate control of new nitrogen input by nitrogen fix- 
ation in the tropical Pacific Ocean, Biogeosciences, 5, 95-109, doi:10.5194/bg-5-95-2008, 2008.

Moutin, T., Van Den Broeck, N., Beker, B., Dupouy, C., Rimmelin, P., and Le Bouteiller, A.: Phosphate availability controls Trichodesmium spp. biomass in the SW Pacific Ocean, Mar. Ecol.Prog. Ser., 297, 15-21, 2005.

Mulholland, M. R., Bernhardt, P. W., Heil, C. A., Bronk, D. A., and O'Neil, J. M.: Nitrogen fixation and release of fixed nitrogen by Trichodesmium spp. in the Gulf of Mexico, Limnol. Oceanogr., 51, 1762-1776, 2006.

Mulholland, M. R., Bronk, D. A., and Capone, D. G.: Dinitrogen fixation and release of ammonium and dissolved organic nitrogen by Trichodesmium IMS101, Aquat. Microb. Ecol., 37, 85-94, 2004.

Mulholland, M. R. and Capone, D. G.: Stoichiometry of nitrogen and carbon utilization in cultured populations of Trichodesmium IMS101: Implications for growth, Limnol. Oceanogr., 46, 436443, 2001

O'Neill, J. M. and Roman, M. R.: Ingestion of the cyanobacterium Trichodesmium spp. by pelagic harpacticoid copepods Macrosetella, Miracia and Oculosetella, Hydrobiologia, 292293, 235-240, 1994.

Press, W. H., Teukolsky, S. A., Vetterling, W. T., and Flannery, B. P.: Numerical Recipes in C: The art of scientific computing, 2nd Edn., Cambridge University Press, 1992.

Pujo-Pay, M. and Raimbault, P.: Improvement of the wet-oxidation procedure for simultaneous determination of particulate organic nitrogen and phosphorus collected on filters, Mar. Ecol.-Prog. Ser., 105, 203-207, 1994.

Rau, G. H., Teyssie, J.-L., Rassoulzadegan, F., and Fowler, S. W.: ${ }^{13} \mathrm{C} /{ }^{12} \mathrm{C}$ and ${ }^{15} \mathrm{~N} /{ }^{14} \mathrm{~N}$ variations among size-fractionated marine particles: implications for their origin and trophic relationships, Mar. Ecol.-Prog. Ser., 59, 33-38, 1990.

Redfield, A. C.: The Biological Control of Chemical Factors in the Environment, Am. Sci., 46, 205-221, 1958.

Rodier, M. and Le Borgne, R.: Population and trophic dynamics of Trichodesmium thiebautii in the SE lagoon of New Caledonia, Comparison with T. erythraeum in the SW lagoon, Mar. Pollut. Bull., 61, 349-359, 2010.

Rodier, M. and Le Borgne, R.: Population dynamics and environmental conditions affecting Trichodesmium spp. (filamentous cyanobacteria) blooms in the south-west lagoon of New Caledonia, J. Exp. Mar. Biol. Ecol., 358, 20-32, 2008.

Roman, M. R.: Ingestion of Blue-Green-Alga Trichodesmium by Harpactacoid Copepod, Macrosetella-Gracilis, Limnol. Oceanogr., 23, 1245-1248, 1978.

Sigman, D. M., Casciotti, K. L., Andreani, M., Barford, C., Galanter, M., and Bohlke, J. K.: A bacterial method for the nitrogen isotopic analysis of nitrate in seawater and freshwater, Anal. Chem., 73, 4145-4153, 2001.
Sigman, D. M., DiFiore, P. J., Hain, M. P., Deutsch, C., Wang, Y., Karl, D. M., Knapp, A. N., Lehmann, M. F., and Pantoja, S.: The dual isotopes of deep nitrate as a constraint on the cycle and budget of oceanic fixed nitrogen, Deep-Sea Res. Pt. I, 56, 1419 1439, 2009.

Solorzano, L. and Sharp, J. H.: Determination of Total Dissolved Nitrogen in Natural-Waters, Limnol. Oceanogr., 25, 751-754, 1980.

Sterner, R. W. and Elser, J. J.: Ecological stoichiometry: the biology of elements from molecules to the biosphere, in: Ecological stoichiometry: the biology of elements from molecules to the biosphere, Princeton, NJ, USA, 2002.

Strickland, J. D. H. and Parsons, T. R.: A practical handbook of seawater analysis, Fisheries Research Board of Canada, Ottowa, 1968.

Swart, P. K., Anderson, W. T., Altabet, M. A., Drayer, C., and Bellmund, S.: Sources of dissolved inorganic nitrogen in a coastal lagoon adjacent to a major metropolitan area, Miami Florida (USA), Appl. Geochem., 38, 134-146, 2013.

Townsend-Small, A., McCarthy, M. J., Brandes, J. A., Yang, L. Y., Zhang, L., and Gardner, W. S.: Stable isotopic composition of nitrate in Lake Taihu, China, and major inflow rivers, Hydrobiologia, 581, 135-140, 2007.

Treibergs, L. A., Fawcett, S. E., Lomas, M. W., and Sigman, D. M.: Nitrogen isotopic response of prokaryotic and eukaryotic phytoplankton to nitrate availability in Sargasso Sea surface waters, Limnol. Oceanogr., 59, 972-985, 2014.

Triola, M. F.: Elementary Statistics, Addison Wesley Longman, New York, NY, 2001.

Turk-Kubo, K. A., Frank, I. E., Hogan, M. E., Desnues, A., Bonnet, S., and Zehr, J. P.: Diazotroph community succession during the VAHINE mesocosm experiment (New Caledonia lagoon), Biogeosciences, 12, 7435-7452, doi:10.5194/bg-12-7435-2015, 2015.

Walsby, A. E.: The gas vesicles and buoyancy of Trichodesmium, in: Marine Pelagic Cyanobacteria: Trichodesmium and other Diazotrophs, edited by: Carpenter, E. J., Capone, D. G., and Rueter, J. G., Springer, Dordrecht, Netherlands, 1992.

Wasmund, N., Nausch, G., and Hansen, A.: Phytoplankton succession in an isolated upwelled Benguela water body in relation to different initial nutrient conditions, J. Mar. Syst., 140, 163-174, 2014.

White, A. E., Spitz, Y. H., Karl, D. M., and Letelier, R. M.: Flexible elemental stoichiometry in Trichodesmium spp. and its ecological implications, Limnol. Oceanogr., 51, 1777-1790, 2006.

Yoshikawa, C., Makabe, A., Shiozaki, T., Toyoda, S., Yoshida, O., Furuya, K., and Yoshida, N.: Nitrogen isotope ratios of nitrate and $\mathrm{N}^{*}$ anomalies in the subtropical South Pacific, Geochem. Geophy. Geosy., 16, 1439-1448, 2015. 